\title{
Eggs for breakfast? Analysis of a probable mosasaur biting trace on the Cretaceous echinoid Echinocorys ovata Leske, 1778
}

\author{
Christian Neumann and Oliver Hampe \\ Museum für Naturkunde - Leibniz-Institut für Evolutions- und Biodiversitätsforschung, Invalidenstrasse 43, \\ 10115 Berlin, Germany
}

Correspondence: Christian Neumann (christian.neumann@mfn-berlin.de)

Received: 28 September 2017 - Revised: 16 January 2018 - Accepted: 19 January 2018 - Published: 28 February 2018

\begin{abstract}
Fossil biting traces (praedichnia) represent indirect evidence of predation and shed light on fossil predatorprey interactions and fossil food webs. Especially from echinoderm skeletons, biting traces are well known. Here, we describe the oral surface of a large Cretaceous (Maastrichtian) holasteroid echinoid Echinocorys ovata Leske, 1778 from Hemmoor (northern Germany) which exhibits four circular punctures arranged in a semi-circular arc. Whereas three of the punctures penetrated the skeleton, one puncture only just hit the margin of the echinoid test at the ambitus, leaving a long incision furrow in the skeleton. The punctures were not lethal to the sea urchin as is indicated by progressed skeletal regeneration and closure of the fractures. The overall appearance of the punctures suggests that they were produced during a single mechanical event, most likely by the biting action of the teeth of a large vertebrate animal. We analysed the shape and arrangement of the biting trace and conclude that it was probably produced by a marine reptile possessing a prognath tooth position, most likely by a globidensine mosasauroid. Our finding not only sheds light on mosasaur feeding behaviour and prey selection but also increases the knowledge of the food webs in the chalk sea ecosystem during the uppermost Cretaceous.
\end{abstract}

\section{Introduction}

Predation plays an important role in modern and ancient ecosystems. Trophic relationships based on predation not only shape communities but also affect the evolution of both predators and their prey. Thus, fossil evidence of predatorprey interactions is important for the understanding of energy flow in ancient ecosystems, food webs, and the arms race between predator and prey. Direct evidence of predation, such as preserved gut contents, coprolites, or regurgitated masses containing identifiable prey remains are rare and exceptional findings. The study of the signs and traces preserved on the hard skeletal parts of prey organisms that reflect predatory behaviour is therefore of exceptional importance. These traces (praedichnia) include skeletal breakage, biting traces, borings, but also regeneration and repair patterns mirroring unsuccessful attacks.

Among marine invertebrates, the study of predation traces found in echinoids (Echinodermata) proves to be peculiarly rewarding. Echinoids are the diet of a wide variety of marine predators including gastropods, crustaceans, starfish, other echinoids, elasmobranch and teleost fish, turtles, birds and marine mammals (Kowalewski and Nebelsick, 2003). Previously, most authors focused on drilling predation by cassid gastropods ("helmet conchs"), since their predatory strategy leaves the echinoid test entirely intact except for a small but diagnostic borehole that can be easily recognized. In contrast, the study of shell-breaking predation is more challenging, assuming that a successful attack would result in the complete destruction of the echinoid test. However, the stereomic nature of the echinoid skeleton favours the preservation of biting traces ("tooth marks") of unsuccessful attacks (Kähn, 1928; Gripp, 1929; Thies, 1985), allowing conclusions to be drawn as to the predator's taxonomic identity. Biting trace analysis is based on the following two concepts or assumptions (Bowers, 2003): (i) the dental characteristics of teeth involved in biting are unique in species level and (ii) this asserted uniqueness is transferred and recorded in the biting trace. As a consequence, ideally preserved biting traces allow conclusions to be made about the predators' dentition and consequently their identity (e.g., Neumann, 2000; Jacob- 
sen and Bromley, 2009). However, the shape and pattern of biting traces is influenced by many factors, which not only include the biters tooth morphology and dental arrangement, which in addition may vary among individuals of one species due to ontogeny or individual wear, but also by biting angle, power of biting force, and nature of the substrate. Moreover, echinoids possess an enormous capability to survive and repair traumatic damage of the test, even when the test is penetrated (Bonasoro et al., 2004; Carnevali, 2006). Hence, skeletal regeneration process of non-lethal lesions produced by a biting attack may alter or even obscure the original shape of the biting trace.

Here, we describe an exceptional biting trace found on the basal-ambital region of a holasteroid echinoid Echinocorys ovata Leske, 1778 from the lower Maastrichtian chalk of Hemmoor. Repair features indicate that the echinoid survived this unsuccessful attack. The large size, circular outline, and arc-shaped arrangement of tooth traces suggests that the echinoid was bitten by a large predator possessing conical pointed teeth, most probably a marine reptile. We hypothesize that the echinoid was bitten by a mosasaur and experimentally tested this assumption by producing biting traces by applying a mosasaur jaw model and echinoid clay dummies.

\section{Material and methods}

Our query for biting traces focussed on the echinoid genus Echinocorys, a common epifaunal deposit-feeding echinoid with a worldwide distribution known from the Turonian (Upper Cretaceous) to the Palaeogene. The applicability of Echinocorys as a model taxon for the ichnofossils-based study of biotic interactions (parasitism, predation) in deeptime has been emphasized in case studies by Neumann and Wisshak (2006, 2009) and Wisshak and Neumann (2006). We examined more than 7000 Echinocorys specimens obtained through our own fieldwork in the chalk of northern Germany as well as from collection specimens stored at the Natural History Museum, Berlin, the Geological Museum, Copenhagen, the Swedish Royal Museum of Natural History, Stockholm and the Federal Institute for Geosciences and Natural Resources (BGR) in Hanover, Germany. Our query resulted in the recognition of numerous predation traces. Among these, a peculiar and outstanding biting trace situated on the test of a large Echinocorys ovata from the Maastrichtian of Hemmoor (MB.E. 6565, stored in the Natural History Museum, Berlin) has been discovered which is described in the present study (Fig. 1a-c).

For descriptive purposes, each tooth imprint has been numbered (P1-P4, see Fig. 1a). Metric measurements of the test dimensions and the biting trace were taken with the aid of a precision slide caliper. Terms generally used to describe teeth (labial, lingual, mesial, distal) are used here to describe the tooth traces, a practice commonly used in forensic bite mark analysis (Bowers, 2003). Photographic documentation of the trace from various angles has been undertaken with a digital DSLR after coating the specimen with ammonium chloride in order to bring out details of ornament.

For the execution of the biting experiment, a resin model skull with a movable jaw and a total length of $53 \mathrm{~cm}$ was produced using the skull of the type specimen of Prognathodon solvayi Dollo, 1889 as a reference (Fig. 2). We decided to build such a model, because the preservation of the original Prognathodon skull (isolated and fragile bones in a metal frame) appeared unsuitable for either producing casts or applying bite experiments. Our choice of Prognathodon solvayi is explained by its completeness, and because it matches the requirements of tooth morphology, tooth position, and stratigraphic and geographic appearance (Lingham-Soliar and Nolf, 1989). Differences in dental ornamentation occurring among different species of the genus (e.g., Lingham-Soliar and Nolf, 1989; Christiansen and Bonde, 2002; Grigoriev, 2013) are negligible in our experiment. In our experiment, biting traces from various angles were produced by pressing the lower and upper jaw of the model into artificial Echinocorys test "dummies" made of modeling clay. The resulting traces were measured, photographed, and compared with the fossil biting trace.

\section{Geological context}

The specimen of interest is of early Maastrichtian age (Belemnella sumensis Zone) and was collected in the inactive quarry at Hemmoor, which is situated about $60 \mathrm{~km}$ west of Hamburg (53 $\left.41^{\prime} 52^{\prime \prime} \mathrm{N} 9^{\circ} 08^{\prime} 07^{\prime \prime} \mathrm{E}\right)$. Previously, the quarry exposed a $141.5 \mathrm{~m}$ thick chalk succession of late early and early late Maastrichtian age (Belemnella sumensis Zone to Tylocidaris baltica/Oxytoma danica Zone, see Schmid et al., 2004). The chalk sediment is truly pelagic with minimal terrigenous influx and was deposited in a distal shelf environment far away from the coast (Schönfeld et al., 1995). Throughout this section, the epifaunal deposit-feeding holasteroid echinoid Echinocorys ovata Leske, 1778 is the most abundant macrofossil. Whereas Echinocorys tests from this locality often exhibit biting traces produced by sharks and teleosts (Gripp, 1929; Thies, 1985; Neumann, 2003), cases of probable mosasauroid predation have not been observed so far.

\section{Results: Description of the biting trace found on Echinocorys ovata}

The Echinocorys specimen exhibiting the biting traces measured $95 \mathrm{~mm}$ in length and $80 \mathrm{~mm}$ in width during life. The test is relatively stout and thick, measuring $4.3 \mathrm{~mm}$ at the base. Although somewhat fragmented with most of the aboral side missing, the oral (i.e., lower) surface of the echinoid is well preserved. In the posterior-central part of the oral surface, four conspicuous punctures (P1-P4) are visible which 


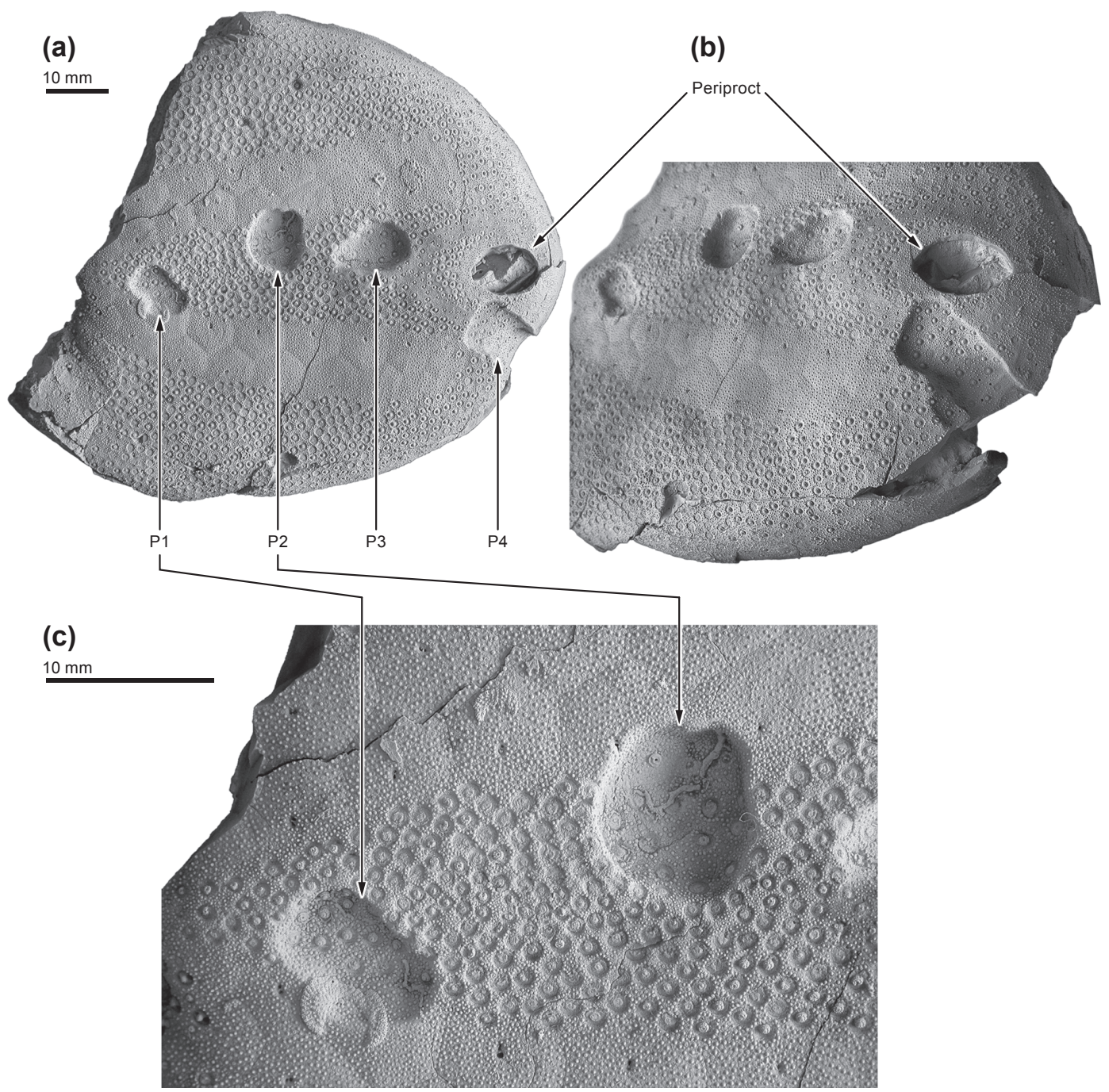

Figure 1. The large deposit-feeding echinoid Echinocorys ovata (MB.E. 6565) from the lower Maastrichtian (Late Cretaceous) of Hemmoor, exposing biting traces: (a) oral surface (posterior to the right) with four tooth punctures (P1-P4); the anterior part of the test is not preserved. (b) Enlarged oblique view showing the broad linear score emanating from P4. (c) Enlarged view showing details of puncture shape and regeneration features of P1 (left) and P2 (right). Note slightly irregular outline of P2 due to chipping. Note that the echinoid's periproct is of comparable size and shape and should not be confused with the punctures.

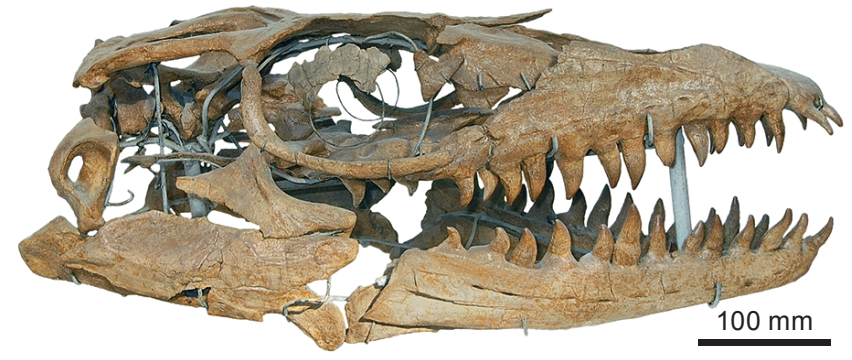

Figure 2. The original skull of Prognathodon solvayi, IRSNB R33, holotype, from the lower Maastrichtian of Mesvin, Belgium, which has been used as a template for the reconstruction of the resin scale model. are arranged in a curved pattern forming a semi-circular arc with a diameter of $70 \mathrm{~mm}$ (Fig. 1a). All punctures except P4 penetrate the plastron area (interambulacrum 5) and also slightly affect the periplastronal areas (ambulacra I and V, respectively). There is a conspicuous symmetry in the size, shape, and interdental distances of the punctures: P1 and P4 are equal in size, ovoid in outline with their long axes (labiallingual) pointing in an oblique angle of 45 and $51^{\circ}$ to the centre line of the arc, respectively. $\mathrm{P} 2$ and $\mathrm{P} 3$ are also equal in size but significantly larger and circular in outline. In P2 and P3 the margins are somewhat irregular because small skeletal fragments have been chipped off during the biting impact. 


\section{Description and measurements}

P1: positioned centrally on plastron area; outline ovoid. Measurements: $9.5 \mathrm{~mm}$ (labiolingually); $5.1 \mathrm{~mm}$ (mesiodistally).

P2: positioned centrally, mostly affecting plastron but also affecting periplastronal area; outline almost circular, slightly irregular probably because small skeletal fragments have been chipped off during the biting impact. Measurements: $9.4 \mathrm{~mm}$ (labiolingually); $8.7 \mathrm{~mm}$ (mesiodistally) (Fig. 1c).

P3: positioned on posterior part of plastron; outline almost circular, slightly irregular. Measurements: $8.7 \mathrm{~mm}$ (labiolingually); $9.7 \mathrm{~mm}$ (mesiodistally); associated with chipping.

P4: positioned on posterior close to periproct and margin; outline ovoid, emanating into broad linear score running along the ambitus towards the lateral side of the echinoid test (Fig. 1b). Measurements: 9.3 (labiolingually); $5.2 \mathrm{~mm}$ (mesiodistally). Length of score: $>13 \mathrm{~mm}$ (not completely preserved).

The interdental distance between $\mathrm{P} 1$ and $\mathrm{P} 2$ is $13.6 \mathrm{~mm}$, between P2 and P3 $6.7 \mathrm{~mm}$, and between P3 and P4 $14.6 \mathrm{~mm}$.

All four punctures are in an equally advanced stage of skeletal regeneration. Whereas the margins of the punctures still possess sharp outlines, the openings have been completely closed with skeletal tissue, and both newly formed primary and secondary tubercles are covering the surfaces of the regenerated skeletal parts.

\section{Discussion}

\subsection{Predator bite vs. alternative explanations of trace formation}

It is necessary to clarify if the observed set of punctures is actually a biting trace or if other biogenic processes can come into consideration. Circular holes or pits in echinoids are known to be produced post-mortem by the drilling activity of bioeroders (Rahman et al., 2015), whereas circular pits may be formed syn vivo by the attachment of parasitic or commensalistic symbionts (Neumann and Wisshak, 2006). A formation of the trace after the echinoids' death can be excluded: the repair features (new formation of skeletal tissue including formation of tubercles) clearly prove that the trace has been formed in the lifetime of the echinoid and that the lesion was not lethal. The echinoid survived at least long enough to repair the injuries. Chipping associated with P2 and P3 and especially the linear score emanating from the well-defined P4 clearly indicate that a physical impact from below rather than a parasite infestation affected the sea urchin. The circumstance that all four punctures are in the same state of regeneration suggests that they were produced at the same time during a single event. Together with the serial, semi-circular arrangement of the punctures, it appears very likely that they were produced by the teeth of a large animal. To produce circular punctures, conical or cylindroconical teeth with pointed tips are required ( $\mathrm{Njau}$ and Blumenshine, 2006).

However, it may appear puzzling that only P2 and P3 are circular in outline and larger while P1 and P4 are smaller and ovoid in outline. A standard mosasauroid jaw will produce the contrary pattern, as the first pair of teeth is generally smaller than the following pairs. Why are there no further punctures preserved? This pattern can be explained by the assumption that the trace was produced by an animal with a prognathous (forward pointing) tooth position. In this case, the frontal pair of teeth would penetrate much deeper and at a steeper angle than the following pair of teeth, thus producing large and circular punctures in contrast to ovoid and small punctures by the following teeth, which hit the echinoid in an oblique angle.

Thus, this distinctive biting trace pattern suggests that the bite must have been produced by a predator with large coneshaped teeth arranged in a prognathous orientation.

The impact leading to the formation of P4 hit the echinoid marginally at the ambitus, causing not only a puncture, but also a long and broad score running along the ambitus towards the lateral side of the echinoid.

The fact that the bite pierced the echinoid without crushing it provides clues for the attacker's prey handling behaviour and biting mechanics. A powerful snapping bite would pierce the echinoid, in contrast to a situation involving a careful, squeezing bite. In contrast to mollusc shells, where the plywood-like arrangement of aragonite or calcite crystals leads to a lateral deflection of the biting force and thus causes irregular breakage, the meshwork structure of the echinoderm skeleton prevents such lateral biting force deflection, leading to punctures mirroring the outline of the biter's teeth (Thies, 1985; Neumann, 2000). Thus, biting traces observed on echinoid skeletons are generally excellently preserved as may be illustrated by a further example of another Echinocorys ovata specimen from the Maastrichtian of Hemmoor (Fig. 3a, b), which exhibits a set of scores produced by the teeth of a teleost or shark (Thies, 1985). Moreover, in this case a large fragment of the plastron has been snapped off during the attack, but the echinoid survived and was able to completely repair the fracture. Another example (Fig. 3c) shows a specimen of the extant spatangoid Spatangus purpureus Müller, 1776 from the Adriatic Sea near Hvar, Croatia, exhibiting a large traumatic fracture affecting a large part of the aboral interambulacrum 4. Amazingly, this large injury was not lethal to the echinoid but has been completely repaired. Echinoids, as with most other echinoderms possess a high potential to repair traumatic injuries of the test, a strik- 

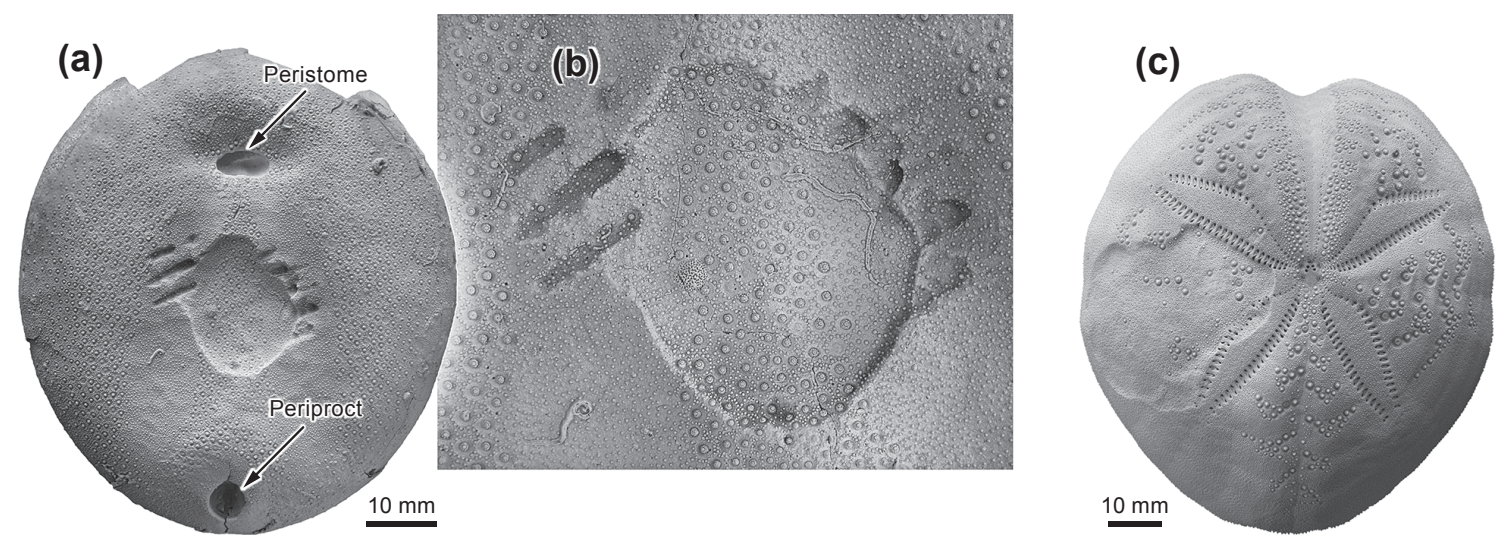

Figure 3. (a) Echinocorys ovata from the Maastrichtian of Hemmoor (BGR 389a/3) in oral view showing biting traces induced by a teleost fish or shark. (b) Detail of (a), showing set of tooth furrows and regenerated fracture. (c) Aboral aspect of living echinoid Spatangus purpureus from Hvar, Croatia (MB.E 11453) with a healed non-lethal fracture affecting large regions of interambulacrum 4.

ing adaptive strategy for survival exploited by this phylum (Bonasoro et al., 2004).

\subsection{Probable biting trace agents}

Various trace makers can be excluded on the basis of the overall morphology of their dentition. Examples of conceivable suspects of Late Cretaceous marine vertebrates which were unable to produce similar biting traces are listed in Table 1. Late Cretaceous large teleost fishes do not match the requirements needed to produce the kind of traces found in the described Echinocorys specimen. Potential teleost candidates have large, conical teeth that alternate with small teeth, a condition found in most predatory teleosts of the Late Cretaceous (see Friedman, 2009). Cretaceous sharks in question, e.g., the widely distributed Squalicorax, do not possess the cone-shaped teeth able to induce rounded biting traces as seen in the Echinocorys in question (Reif, 1973; Schwimmer et al., 1997a; Motta, 2004; Becker and Chamberlain, 2012).

In dyrosaurid crocodylians, the premaxillae are relatively narrow and very slightly inflated laterally relative to the width of the maxillae, resulting in a narrower arc of front teeth. Each premaxilla bears four alveoli, the first tooth usually being the smallest, the third tooth being the largest (e.g., Jouve et al., 2006). Dyrosaurids are documented from Late Cretaceous to Eocene sediments along the Atlantic Ocean and Tethys Sea margins (Khosla et al., 2009). Certain remains of the Dyrosauridae of predominantly Maastrichtian age have been found on the east coast of North America (Denton et al., 1997), in Argentina (Gasparini and Spalletti, 1990), Mali (Brochu et al., 2002), Sudan (Salih et al., 2016), and India (Rana and Sati, 2000). No contemporary remains are recorded to date from European deposits. Only uncertain remains of Cenomanian age have been found in Portugal (Buffetaut and Lauverjat, 1978).

Pliosaurs disappeared more than $20 \mathrm{Ma}$ before the Echinocorys record described here, with the Turonian
Brachauchenius lucasi as the last survivor of the group (Hampe, 2005; Ketchum and Benson, 2010; Fischer et al., 2015). Other sauropterygians can also be excluded with high probability, although recent discoveries of elasmosaur stomach contents, mainly including benthic invertebrates, have been reported from the Lower Cretaceous in Australia (McHenry et al., 2005). The Australian research group suggests a bottom feeding habitus for these Late Mesozoic longnecked plesiosaurs usually interpreted as fish- and squidfeeders.

Although some elasmosaurs possess prognathous anterior tooth pairs, tooth and skull sizes in most cases do not correspond to the traces found in the Echinocorys test. Moreover, these sauropterygians lived in a different time-slice (see Table 1). The fragility of the elasmosaurid skull and the needlelike associated teeth are probably more suitable for piscivorous feeding or soft prey diets (see above, and Massare, 1987; Everhart, 2005). For the time being we cannot prove the possibility of sauropterygians producing the biting trace because of the incompleteness of records in the latest Mesozoic. Several isolated vertebrae and insignificant teeth have been reported from the latest Cretaceous worldwide (Mulder et al., 2000; Vincent et al., 2011), but the discussion shows that the type of teeth and the usually significantly lower degree of prognath anterior dentition excludes the possibility that the echinoid was bitten by a plesiosaur.

A closer look at the morphology of the jaws and dentition of the Late Cretaceous rulers of the epicontinental seas, the mosasauroids, reveals eliminating factors that leave only a few taxa as candidates for having caused the biting trace on the investigated Hemmoor echinoid. The Tylosaurinae, for example, could be withdrawn from the list because they do not possess terminal teeth. Tylosaurinae developed large, prolonged rostra anterior to the premaxillary teeth (e.g., Russell, 1967; Bullard and Caldwell, 2010). The Plioplatecarpinae, the second group of derived Russellosau- 
Table 1. Examples for excluded non-mosasauroid causers of the German Echinocorys bite traces. Positions which are not congruent with the finding are in bold.

\begin{tabular}{|c|c|c|c|}
\hline Taxon & Representative source & Morphology & Age/Record \\
\hline Elasmobranchii & Reif (1973); Motta (2004) & non-cone-shaped teeth & Cretaceous \\
\hline $\begin{array}{l}\text { Ichthyodectiformes } \\
\text { (e.g., Xiphactinus) }\end{array}$ & Schwimmer et al. (1997b) & $\begin{array}{l}\text { not all species possess procumbent } \\
\text { anterior teeth }\end{array}$ & $\begin{array}{l}\text { unknown from Euro- } \\
\text { pean Maastrichtian }\end{array}$ \\
\hline Euteleostei & Friedman (2009) & $\begin{array}{l}\text { often numerous fanglike conical teeth } \\
\text { alternated by small teeth }\end{array}$ & Late Cretaceous \\
\hline Dyrosauridae & Khosla et al. (2009) & $\begin{array}{l}\text { narrow arc of front teeth, different } \\
\text { tooth sizes }\end{array}$ & $\begin{array}{l}\text { no contemporary } \\
\text { records in Europe }\end{array}$ \\
\hline Pliosauridae & $\begin{array}{l}\text { Ketchum and Benson (2010); } \\
\text { Fischer et al. (2015) }\end{array}$ & procumbent anterior teeth known & $\begin{array}{l}\text { disappeared more than } \\
20 \text { Ma before Echinoco- } \\
\text { rys record }\end{array}$ \\
\hline $\begin{array}{l}\text { Aristonectes parvidens (and the } \\
\text { following = Elasmosauridae) }\end{array}$ & $\begin{array}{l}\text { Cabrera (1941); Gasparini et } \\
\text { al. (2003); O'Gorman (2016) }\end{array}$ & $\begin{array}{l}\text { relatively large cranium }(0.73 \mathrm{~m} \\
\text { length); jaw bones containing nu- } \\
\text { merous tiny alveoles }\end{array}$ & $\begin{array}{l}\text { Maastrichtian of the Wed- } \\
\text { dellian Sea }\end{array}$ \\
\hline Elasmosaurus platyurus & Sachs (2005) & prognathous dentition & $\begin{array}{l}\text { early Campanian of } \\
\text { Kansas }\end{array}$ \\
\hline Hydrotherosaurus alexandriae & Welles (1943) & $\begin{array}{l}\text { skull length only } 0.33 \mathrm{~m} \text {; remarkable } \\
\text { irregular dentition, not procumbent }\end{array}$ & $\begin{array}{l}\text { Campanian-Maastrichtian } \\
\text { of California }\end{array}$ \\
\hline Kaiwhekea katiki & $\begin{array}{l}\text { Cruickshank and Fordyce } \\
\text { (2002) }\end{array}$ & $\begin{array}{l}\text { small and homodontous needle- } \\
\text { shaped teeth; skull length } 0.62 \mathrm{~m}\end{array}$ & $\begin{array}{l}\text { Maastrichtian of New } \\
\text { Zealand }\end{array}$ \\
\hline Libonectes morgani & Carpenter $(1997,1999)$ & $\begin{array}{l}\text { premaxillae and dentary with prog- } \\
\text { nathous anterior tooth pairs }\end{array}$ & early Turonian of Texas \\
\hline Styxosaurus snowi & $\begin{array}{l}\text { Welles (1952); Carpenter } \\
\text { (1999) }\end{array}$ & $\begin{array}{l}\text { prognath, but skull too short }(0.47 \mathrm{~m}) \\
\text { and slender teeth }\end{array}$ & $\begin{array}{l}\text { Coniacian-Santonian of } \\
\text { Texas }\end{array}$ \\
\hline Terminonatator ponteixensis & Sato (2003) & $\begin{array}{l}\text { skull length } \mathbf{0 . 2 6} \mathbf{~ m} \text {; anteriorly procum- } \\
\text { bent teeth }\end{array}$ & $\begin{array}{l}\text { late Campanian of } \\
\text { Saskatchawan }\end{array}$ \\
\hline Tuarangisaurus keyesi & $\begin{array}{l}\text { Wiffen and Moisley (1986); } \\
\text { Carpenter (1999) }\end{array}$ & $\begin{array}{l}\text { long and narrow teeth, skull length } \\
0.37 \mathrm{~m} \text {; premaxillary teeth inter- } \\
\text { locked with dentary teeth which are } \\
\text { meagerly prognath }\end{array}$ & $\begin{array}{l}\text { Maastrichtian of New } \\
\text { Zealand }\end{array}$ \\
\hline $\begin{array}{l}\text { Dolichorhynchops herschelensis } \\
\text { (= Polycotylidae) }\end{array}$ & Sato (2005) & $\begin{array}{l}\text { extremely narrow arrangement of } \\
\text { teeth (in parallel) }\end{array}$ & $\begin{array}{l}\text { late Campanian-early } \\
\text { Maastrichtian of } \\
\text { Saskatchewan }\end{array}$ \\
\hline
\end{tabular}

rina have short heads, but a predental rostrum is absent. As a typical representative, Platecarpus, which occurred from the Santonian to early Campanian, has recurved, not procumbent teeth (Russell, 1967; Konishi and Caldwell, 2007), and is also an older form. Plioplatecarpus has proportionally small anteriormost teeth but they can be somewhat procumbent (Holmes, 1996). Halisaurus has small, recurved premaxillary teeth with delicate crowns (Bardet et al., 2005a). Clidastes of the Mosasaurinae could also be released as the biting trace producer because of its small and not procumbent anterior teeth (Williston, 1925; Russell, 1967). Species of the eponymous genus Mosasaurus possess procumbent premaxillary teeth to a certain degree, but they are proportionally small (see Lingham-Soliar, 1995; Mulder, 1999; Konishi et al., 2014) and certainly not favoured to handle sea urchins with effortlessness.

Having eliminated the above taxa, we are left with the globidensine mosasaurs as contenders, in which Prognathodon has large forward-pointed conical teeth and was widespread in late Campanian to early Maastrichtian strata of the Cretaceous North Sea basin (Dortangs et al., 2002; Machalski et al., 2003; Lindgren, 2004). Early ontogenetic stages of other Globidensini (Carinodens, Globidens) may also show prognath dentition (see below) and thus may also come into consideration as producers of the biting trace. At least, Carinodens also occurs in the Maastrichtian chalk of the North Sea 

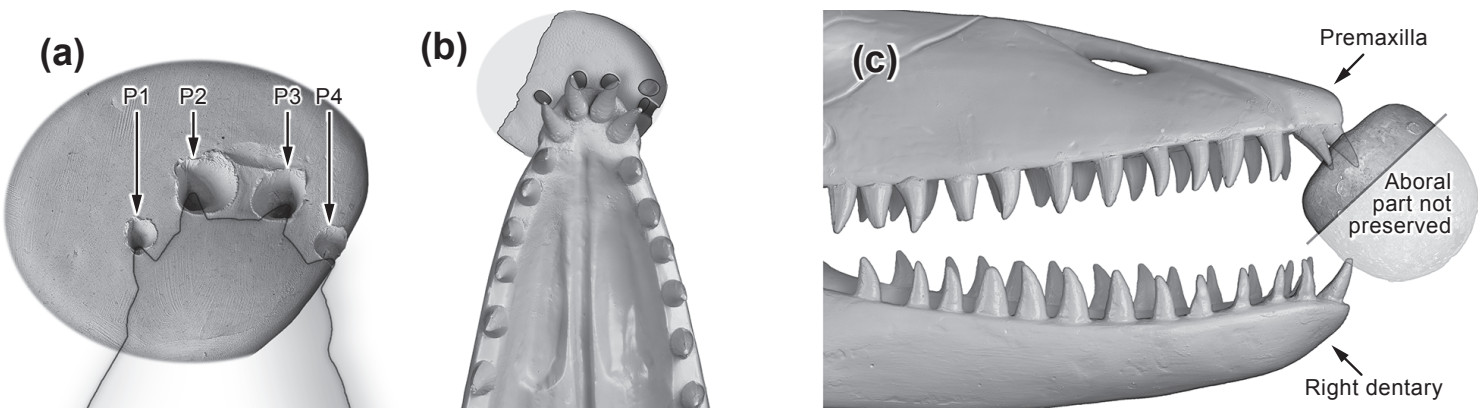

Figure 4. Result of bite mark experiment: (a) Echinocorys clay dummy with superimposed shadow of a mosasaur upper jaw showing four biting traces artificially produced by the two anteriormost (premaxillary) tooth pairs of a mosasaur scale model. (b) Upper jaw of the mosasaur scale model superimposed over the Echinocorys ovata biting trace demonstrating conformity of tooth traces and globidensine mosasaur tooth arrangement. (c) Lateral view of the mosasaur scale model reconstructing the biting angle which produced the distinct biting trace. Note the prognathous arrangement of the premaxillary teeth and their different penetration angle and depth. The shaded area of the echinoid is not preserved in the original.

basin (Milàn et al., 2017). The likelihood that Mosasaurus hoffmanni (Mulder, 1999), a common inhabitant of the North Sea basin, is the agent is not very probable as outlined in the paragraph before.

\subsection{Experimental testing of the globidensine mosasaur hypothesis}

We tested our hypothesis using techniques adopted from forensic odontology (ABFO, 1986; Rai et al., 2006) applying biting experiments with an original-scale resin model of the skull based on the holotype of Prognathodon solvayi (Dollo, 1889) and Echinocorys clay dummies. Casts of original Prognathodon teeth from Maastrichtian phosphates of Morocco were applied imitating the dentition. We produced a series of biting traces applying varying biting angles and biting forces. The tooth traces on the fossil echinoid and those produced by the anteriormost teeth of the upper jaw (premaxillae) in our experiment show a striking resemblance (Figs. 1a, 3a) where P1 has been produced by the second left premaxillar tooth, P2 by the first left, P3 by the first right and $\mathrm{P} 4$ by the second right premaxillar tooth (Fig. $4 \mathrm{a}-\mathrm{c}$ ).

We could state that the producer was very probably a representative of the Globidensini (Fig. 5). In our experiment, the traces fit in size and arrangement with the fossil finding. Nevertheless, other globidensine taxa besides Prognathodon cannot generally be excluded. Globidens and Carinodens can also have anterior prognathid dentition (e.g., Bardet et al., 2005b; Schulp, 2005) and there is an ontogentic change in tooth form documented for Globidens (Polcyn and Bell, 2005), with young animals possessing a very Prognathodonlike dentition. Regarding size and proportion, a producer of an early ontogenetic stage is very unlikely in our case.

\subsection{Palaeoecological and palaeobiological implications}

Mosasaur biting traces (including Prognathodon) on invertebrate skeletons have been documented so far from the shells of ammonitid and nautilitid cephalopods (Kauffman and Kesling, 1960; Kauffman, 2004), demonstrating that nondurophagous mosasaurs were able to feed on hard-shelled, nektonic prey. Although some authors questioned whether these traces were produced by biting mosasaurs (Seilacher, 1998), further work on this subject has accumulated much evidence that this interpretation was correct (Tsujita and Westermann, 2001). So far, no evidence of mosasaur predation on echinoids exists. Dollo (1913) mentioned a Hemipneustes echinoid as prey of Prognathodon. The echinoid was deposited above the mosasaur skeleton at a later time interval, but was superimposed on the mosasaur skeleton, due to low sedimentation rate (John W. M. Jagt, personal communication, 2008). Thus, this finding represents a preservation effect rather than predation evidence. Donovan et al. (2008) suggested mosasaur predation on Hemipneustes, but the evidence is poor and must be regarded as dubious since it is merely based on a single round pit on the echinoid test.

Our hypothesis challenges the common assumption that the nature of the prey is tightly constrained to the prey type considered optimal for a given predator tooth morphology. Globidensine mosasaurs have a powerful jaw with large blunt to pointed conical teeth pre-adapted for large, fleshy but also osseous prey (see also Massare, 1987). Our example illustrates that Globidensini such as Prognathodon were also able to feed on benthic armoured invertebrates such as sea urchins. Indeed, the prognathous alignment of Prognathodon's anteriormost teeth appears to be suitable for picking up benthic prey from the sea floor. Moreover, we argue that top predators such as Prognathodon probably possessed considerable variation in foraging and feeding techniques, including benthic foraging. We assume that in the pelagic and nutrient-poor chalk-sea (e.g., Voigt and Schön- 


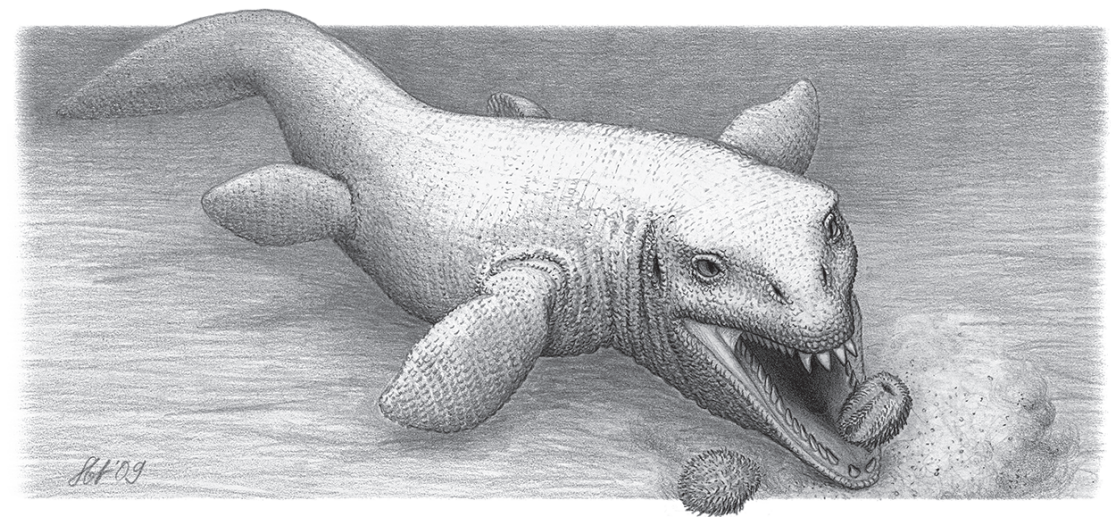

Figure 5. Artist's view of a globidensine mosasaur (based on the Prognathodon model) at the bottom of the chalk-sea feeding on benthic Echinocorys sea urchins (artwork: Elke Siebert).

feld, 2010; Engelke et al., 2016; Linnert et al., 2016), advantage was taken of sea urchins, which were probably the most frequently encountered prey (Fig. 5). Predatory damage caused by vertebates observed in sea urchin tests from the chalk (e.g., Gripp, 1929; Thies, 1985; Neumann, 2003) suggests that they probably represented a major food source for a variety of predators, and most likely played an important role in the benthic-pelagic coupling and the energy flow in the chalk-sea ecosystem. In modern seas, vertebrate predators such as the Atlantic wolffish (Anarhichas lupus) depend on sea urchins as a food source when their preferred prey is scarce or absent; even though the energy content of sea urchins is relatively low (Liao and Lucas, 2000). In the Late Cretaceous of NW Europe, mosasaur remains are more common in neritic sediments (Machalski et al., 2003; Lindgren and Jagt, 2005; Hornung and Reich, 2015; Sachs et al., 2015) than in the pelagic chalk, suggesting a preference for nearshore habitats. Although the European pelagic chalk-sea was probably not the optimal habitat for mosasaurs, their capability for opportunistic feeding allowed them to exploit available nutrient resources in this harsh environment, which otherwise might have represented a barrier for mosasaur migration and dispersal.

A modern analogy for this hypothesis is documented for other marine top predators, like tiger sharks (Galeocerdo cuvieri). They are able to change or modify their foraging tactics with changing habitats and changing food availability (Compagno, 1984). A large dietary range has also been reported, for example, from toothed whales (Orcinus orca: Tomilin, 1957; Jefferson et al., 1991; Visser, 2005). Furthermore, juvenile saltwater crocodiles (Crocodylus porosus) already show opportunistic food intake (Taylor, 1979). Among mosasaurs, Tylosaurus proriger has a well documented history of being an opportunistic feeder with stomach contents revealing teleost remains, other mosasaurs (Clidastes), plesiosaurs, and Hesperornis (Martin and Bjork, 1987; Everhart, 2004). Cephalopods are also reported from stomach contents of Tylosaurus and possibly from Progathodon (Konishi et al.,
2014). However, the dentition tells us that Globidens, Carinodens, and Prognathodon were likely better suited for crushing hard shelled prey than other mosasaurs (Lingham-Soliar, 1999; Bardet et al., 2005b; Schulp, 2005; Martin and Fox, 2007), but they could also process the ordinary mosasaur diet. Other mosasaurs mostly killed their prey with powerful bites and swallowed it whole (Everhart, 2017). Robbins et al. (2008) utilized carbon stable isotopes to demonstrate segregation of foraging habits in mosasaurs at both a taxonomic and ontogenetic level. According to their results, adult Prognathodon and Globidens both exhibit an enriched $\delta^{13} \mathrm{C}$ value, indicating a long submergence, suggesting bottom feeding for both genera (see for more detailed discussion to effects regarding body size and diving in Schulp et al., 2013).

\section{Summary}

A biting trace found on the oral surface of the holasteroid echinoid Echinocorys ovata from the Maastrichtian of Hemmoor is attributed an the attack from a globidensine mosasaur, most probably belonging to the genus Prognathodon. The plausibility of this hypothesis was successfully tested by executing biting experiments with a mosasaur jaw model and artificial echinoid dummies, resulting in similar trace patterns. Our finding is the first plausible record of mosasaur predation upon echinoids. The observations indicate that mosasaurs were opportunistic top predators taking advantage of all available prey, including benthic shelled invertebrates. The chalk sea ecosystem most likely represented a nutrient-starved environments where prey selection was quantity-selective, favouring predators with an opportunistic prey selection strategy.

Data availability. Fossils, the mosasaur resin model, and the clay dummies are stored in the fossil invertebrate collection of the $\mathrm{Mu}$ - 
seum für Naturkunde - Leibniz-Institut für Evolutions- und Biodiversitätsforschung in Berlin, Germany.

Competing interests. Due to the nature of the "special issue" for which this paper was created, the editor shares affiliative ties with the authors. Nonetheless, the authors declare that they have no conflict of interest.

Special issue statement. This article is part of the special issue "Secondary adaptation of tetrapods to life in water - Proceedings of the 8th International Meeting, Berlin 2017”. It is a result of the 8th International Meeting on the Secondary Adaptation of Tetrapods to Life in Water, Berlin, Germany, 3-8 April 2017.

Acknowledgements. We thank Etienne Steurbaut (Brussels) for access to the type specimen of Prognathodon solvayi. Thomas Wiese (Hanover) is acknowledged for the loan of specimens in his care. Markus Brinkmann (Berlin) constructed the mosasaur scale model for the experimental work. Elke Siebert (Berlin) prepared the drawings. Hwaja Götz and Carola Radke (both Berlin) provided technical help. We are grateful to Gloria Arratia (Lawrence, Kansas) for comments on Cretaceous predatory fish. John W. M. Jagt (Maastricht) provided valuable hints on literature. Our special thanks go to Erle G. Kauffman (Bloomington, Indiana), and Michael J. Everhart (Hays, Kansas) for their insightful comments, advice and criticism on earlier drafts of the manuscript which significantly improved its content. We are also grateful to Nathalie Bardet (Paris), Andreas Kroh (Vienna), Judith Pardo-Pérez (Stuttgart), and Bruce M. Rothschild (Pittsburgh) for their efforts and constructive support during the review process.

Edited by: Florian Witzmann

Reviewed by: Andreas Kroh, Nathalie Bardet, Bruce Rothschild, and Judith Pardo Perez

\section{References}

ABFO (American Board of Forensic Odontology): Guidelines for bitemark analysis, J. Am. Dent. Assoc., 112, 383-386, 1986.

Bardet, N., Pereda Suberbiola, X., Iarochene, M., Bouya, B., and Amaghzaz, M.: A new species of Halisaurus from the Late Cretaceous phosphates of Morocco, and the phylogenetical relationships of the Halisaurinae (Squamata: Mosasauridae), Zool. J. Linn. Soc.-Lond., 143, 447-472, 2005a.

Bardet, N., Suberbiola, X. P., Iarochène, M., Amalik, M., and Bouya, B.: Durophagous Mosasauridae (Squamata) from the Upper Cretaceous phosphates of Morocco, with description of a new species of Globidens, Neth. J. Geosci., 84, 167-176, 2005 b.

Becker, M. A. and Chamberlain, J. A. Jr.: Squalicorax chips a tooth: A consequence of feeding-related behavior from the lowermost Navesink Formation (Late Cretaceous: CampanianMaastrichtian) of Monmouth County, New Jersey, USA, Geosciences, 2, 109-129, 2012.

Bonasoro, F., Ferro, P., Di Benedetto, C., Sugni, M., Mozzi, D., and Carnevali, M. C.: Regenerative potential of echinoid test, in:
Echinoderms: München: Proceedings of the 11th International Echinoderm Conference, 6-10 October 2003, Munich, Germany, edited by: Heinzeller, T. and Nebelsick, J. H., CRC Press, Munich, 97-103, 2004.

Bowers, M. C.: Recognition, Documentation, evidence collection, and interpretation of bitemark evidence, in: Forensic Dental Evidence - An Investigator's Handbook, edited by: Bowers, M. C., 93-126, Elsevier, Amsterdam, 2003.

Brochu, C. A., Bouaré, M. L., Sissoko, F., Roberts, E. M., and O'Leary, M. A.: A dyrosaurid crocodyliform braincase from Mali, J. Paleont., 76, 1060-1071, 2002.

Buffetaut, É. and Lauverjat, J.: Un crocodilien d'un type particulier dans le Cénomanien de Nazaré (Portugal), C. R. Somm. Sc. Géol. France, 2, 79-82, 1978.

Bullard, T. S. and Caldwell, M. W.: Redescription and rediagnosis of the tylosaurine mosasaur Hainosaurus pembinensis Nicholls, 1988, as Tylosaurus pembinensis (Nicholls, 1988), J. Vertebr. Paleontol., 30, 416-426, 2010.

Cabrera, A.: Un plesiosaurio nuevo del Cretáceo del Chubut, Revista del Museo de La Plata (Nueva serie), Sección Paleontología, 2, 113-130, 1941.

Carnevali, M. C.: Regeneration in Echinoderms: repair, regrowth, cloning, ISJ-Invert. Surviv. J., 3, 64-76, 2006.

Carpenter, K.: Comparative cranial anatomy of two North American Cretaceous plesiosaurs, in: Ancient marine reptiles, edited by: Callaway, J. M. and Nicholls, E. L., Academic Press, San Diego, 191-216, 1997.

Carpenter, K.: Revision of North American elasmosaurs from the Cretaceous of the Western Interior, Paludicola, 2, 148-173, 1999.

Compagno, L. J. V.: FAO species catalogue, Vol. 4, Sharks of the world, Part 2 - Carcharhiniformes, FAO Fish Syn., 125, 251655, 1984.

Christiansen, P. and Bonde, N.: A new species of gigantic mosasaur from the Late Cretaceous of Israel, J. Vertebr. Paleontol., 22, 629-644, 2002.

Cruickshank, A. R. I. and Fordyce, R. E.: A new marine reptile (Sauropterygia) from New Zealand: further evidence for a Late Cretaceous austral radiation of cryptoclidid plesiosaurs, Palaeontology, 45, 557-575, 2002.

Denton, R. K. Jr., Dobie, J. L., and Parris, D. C.: The marine crocodilian Hyposaurus in North America, in: Ancient marine reptiles, edited by: Callaway, J. M. and Nicholls, E. L., Academic Press, San Diego, 375-397, 1997.

Dollo, L.: Note sur les vertébrés récemments offerts au Musée de Bruxelles par M. Alfred Lemonnier, Bulletin de la Société belge de Géologie, de Paléontologie et d'Hydrologie, 3, 181$182,1889$.

Dollo, L.: Globidens fraasi, mosasaurien mylodonte nouveau du Maestrichtien (Crétacé supérieur) du Limbourg, et l'éthologie de la nutrition chez les mosasauriens, Arch. Biol., 28, 609-626, 1913.

Donovan, S. K., Jagt, J. W. M., and Lewis, D. N.: Ichnology of Late Cretaceous echinoids from the Maastrichtian type area (The Netherlands, Belgium) - 1. A healed puncture wound in Hemipneustes striatoradiatus (Leske), Bull. Mizunami Fossil Mus., 34, 73-76, 2008.

Dortangs, R. W., Schulp, A. S., Mulder, E. W. A., Jagd, J. W. M., Peeters, H. H. G., and Graaf, D. T. de.: A large new mosasaur 
from the Upper Cretaceous of the Netherlands, Neth. J. Geosci., $81,1-8,2002$.

Engelke, J., Esser, K. J., Linnert, C., Mutterlose, J., and Wilmsen, M.: The benthic macrofauna from the Lower Maastrichtian chalk of Kronsmoor (northern Germany, Saturn quarry): taxonomic outline and palaeoecologic implications, Acta Geol. Pol., 66, 671-694, 2016.

Everhart, M. J.: Plesiosaurs as the food of mosasaurs; new data on the stomach contents of a Tylosaurus proriger (Squamata; Mosasauridae) from the Niobrara Formation of western Kansas, The Mosasaur, 7, 41-46, 2004.

Everhart, M. J.: Elasmosaurid remains from the Pierre Shale (Upper Cretaceous) of western Kansas. Possible missing elements of the type specimen of Elasmosaurus platyurus Cope 1868?, PalArch., 4, 19-32, 2005.

Everhart, M. J.: Oceans of Kansas: A natural history of the Western Interior Sea, Indiana University Press, Bloomington, IN, 2017.

Fischer, V., Arkhangelsky, M. S., Stenshin, I. M., Uspensky, G. N., Zverkov, N. G., and Benson, R. B. J.: Peculiar macrophagous adaptations in a new Cretaceous pliosaurid, R. Soc. Open Sci., 2, 150552, https://doi.org/10.1098/rsos.150552, 2015.

Friedman, M.: Ecomorphological selectivity among marine teleost fishes during the end-Cretaceous extinction, P. Natl. Acad. Sci. USA, 106, 5218-5223, 2009.

Gasparini, Z. and Spalletti, L. A.: Un nuevo cocodrilo en los depositos mareales Maastrichtianos de la Patagonia noroccidental, Ameghiniana, 27, 141-150, 1990.

Gasparini, Z., Bardet, N., Martin, J. E., and Fernandez, M.: The elasmosaurid plesiosaur Aristonectes Cabrera from the latest Cretaceous of South America and Antarctica, J. Vertebr. Paleontol., 23, 104-115, 2003.

Grigoriev, D. V.: Redescription of Prognathodon lutugini (Squamata, Mosasauridae), Proc. Zool. Inst. RAS, 317, 246-261, 2013.

Gripp, K.: Über Verletzungen an Seeigeln aus der Kreide Norddeutschlands, Palaeont. Z., 11, 238-245, 1929.

Hampe, O.: Considerations on a Brachauchenius skeleton (Pliosauroidea) from the lower Paja Formation (upper Barremian) of Colombia, Mitt. Mus. Naturk. Berlin, Geowiss. R., 8, 37-51, 2005.

Holmes, R.: Plioplatecarpus primaevus (Mosasauridae) from the Bearpaw Formation (Campanian, Upper Cretaceous) of the North American Western Interior Seaway, J. Vertebr. Paleontol., 16, 673-687, 1996.

Hornung, J. J. and Reich, M.: Tylosaurine mosasaurs (Squamata) from the Late Cretaceous of northern Germany, Neth. J. Geosci., 94, 55-71, 2015.

Jacobsen, A. R. and Bromley, R. G.: New ichnotaxa based on tooth impressions on dinosaur and whale bones, Geol. Q., 53, 373382, 2009.

Jefferson, T. A., Stacey, P. J., and Baird, R. W.: A review of killer whale interactions with other marine mammals: predation to coexistence, Mammal Rev., 21, 151-180, 1991.

Jouve, S., Iarochène, M., Bouya, B., and Amaghzaz, M.: A new species of Dyrosaurus (Crocodylomorpha, Dyrosauridae) from the early Eocene of Morocco: phylogenetic implications, Zool. J. Linn. Soc.-Lond., 148, 603-656, 2006.
Kauffman, E. G.: Mosasaur predation on Upper Cretaceous nautiloids and ammonites from the United States Pacific coast, Palaios, 19, 96-100, 2004.

Kauffman, E. G. and Kesling, R. V.: An Upper Cretaceous ammonite bitten by a mosasaur, Univ. Mich. Contrib. Mus. Paleont., 15, 193-248, 1960.

Kähn, H.: Ein Gehäuse von Echinocorys (Ananchytes) ovatus Leske mit Kerben, ihre Herkunft und sedimentpetrogenetische Auswertung, speziell bezüglich der Feuersteinentstehung, Palaeobiologica, 1, 251-262, 1928.

Ketchum, H. F. and Benson, R. B. J.: Global interrelationships of Plesiosauria (Reptilia, Sauropterygia) and the pivotal role of taxon sampling in determining the outcome of phylogenetic analyses, Biol. Rev., 85, 361-392, 2010.

Khosla, A., Sertich, J. J. W., Prasad, G. V. R., and Verma, O.: Dyrosaurid remains from the Intertrappean Beds of India and the Late Cretaceous distribution of Dyrosauridae, J. Vertebr. Paleont., 29, 1321-1326, 2009.

Konishi, T. and Caldwell, M. W.: New specimens of Platecarpus planifrons (Cope, 1874) (Squamata: Mosasauridae) and a revised taxonomy of the genus, J. Vertebr. Paleontol., 27, 59-72, 2007.

Konishi, T., Newbrey, M. G., and Caldwell, M. W.: A small, exquisitely preserved specimen of Mosasaurus missouriensis (Squamata, Mosasauridae) from the upper Campanian of the Bearpaw Formation, western Canada, and the first stomach contents for the genus, J. Vertebr. Paleontol., 34, 802-819, 2014.

Kowalewski, M. and Nebelsick, J. H.: Predation on recent and fossil echinoids, in Predator-prey interactions in the fossil record: Topics in Geobiology Series, edited by: Kelley, P. H., Kowalewski, M., and Hansen, T. A., 279-302, Kluwer Academic/Plenum, New York, 2003.

Leske, N. G.: Additamenta ad Jacobi Theodori Klein naturalem dispositionem echinodermatum et lucubratiunculam de aculeis echinorum marinorum, Gleditsch, Leipzig, Germany, 1778.

Lindgren, J.: Stratigraphical distribution of Campanian and Maastrichtian mosasaurs in Sweden - evidence of an intercontinental marine extinction event?, GFF, 126, 221-229, 2004.

Lindgren, J. and Jagt, J. W. M.: Danish mosasaurs, Neth. J. Geosci., 84, 315-320, 2005.

Lingham-Soliar, T.: Anatomy and functional morphology of the largest marine reptile known, Mosasaurus hoffmanni (Mosasauridae, Reptilia) from the Upper Cretaceous, upper Maastrichtian of the Netherlands, Philos. T. Roy. Soc. B, 347, 155-180, 1995.

Lingham-Soliar, T.: The durophagous mosasaurs (Lepidosauromorpha, Squamata) Globidens and Carinodens from the Upper Cretaceous of Belgium and The Netherlands, Paleontol. J., 33, 638647, 1999.

Lingham-Soliar, T. and Nolf, D.: The mosasaur Prognathodon (Reptilia, Mosasauridae) from the Upper Cretaceous of Belgium, Bull. Inst. roy. Sci. nat. Belgique, Sci. Terre, 59, 137-190, 1989.

Linnert, C., Engelke, J., Wilmsen, M., and Mutterlose, J.: The impact of the Maastrichtian cooling on the marine nutrient regime - Evidence from midlatitudinal calcareous nannofossils, Paleoceanography, 31, 694-714, 2016.

Liao, Y.-Y. and Lucas, M. C.: Growth, diet and metabolism of common wolf-fish in the North Sea, a fast growing population, J. Fish Biol., 56, 810-825, 2000. 
Machalski, M., Jagt, J. W., Dortangs, R. W., Mulder, E. W., and Radwanski, A.: Campanian and Maastrichtian mosasaurid reptiles from central Poland, Acta Palaeont. Pol., 48, 397-408, 2003.

Martin, J. E. and Bjork, P. R.: Gastric residues associated with a mosasaur from the late Cretaceous (Campanian) Pierre Shale in South Dakota, Dakoterra, 3, 68-72, 1987.

Martin, J. E. and Fox, J. E.: Stomach contents of Globidens, a shellcrushing mosasaur (Squamata), from the Late Cretaceous Pierre Shale Group, Big Bend area of the Missouri River, central South Dakota, in: The Geology and Paleontology of the Late Cretaceous Marine Deposits of the Dakotas, edited by: Martin, J. E. and Parris, D. C., Geol. Soc. Am. Spec. Pap., 427, 167-176, 2007.

Massare, J. A.: Tooth morphology and prey preference of Mesozoic marine reptiles, J. Vertebr. Paleontol., 7, 121-137, 1987.

McHenry, C. R., Cook, A. G., and Wroe, S.: Bottom-feeding plesiosaurs, Science, 310, p. 75, 2005.

Milàn, J., Jagt, J. W. M., Lindgren, J., and Schulp, A. S.: First record of Carinodens (Squamata, Mosasauridae) from the uppermost Maastrichtian of Stevns Klint, Denmark, Alcheringa, https://doi.org/10.1080/03115518.2017.1391878, online first, 2017.

Motta, P. J.: Prey capture behavior and feeding mechanics of elasmobranchs, in: Biology of sharks and their relatives, edited by: Carrier, J. C., Musick, J. A., and Heithaus, M. R., CRC, Boca Raton, 165-202, 2004.

Müller, O. F.: Zoologiae Danicae prodromus: seu Animalium Daniae et Norvegiae indigenarum characteres, nomina, et synonyma imprimis popularium, Copenhagen, 1776.

Mulder, E. W. A.: Transatlantic latest Cretaceous mosasaurs (Reptilia, Lacertilia) from the Maastrichtian type area and New Jersey, Geol. Mijnbouw, 78, 281-300, 1999.

Mulder, E. W. A., Bardet, N., Godefroit, P., and Jagt, J. W. M.: Elasmosaur remains from the Maastrichtian type area, and a review of Latest Cretaceous elasmosaurs (Reptilia, Plesiosauroidea), Bull. Inst. Roy. Sci. Nat. Belgique Sci. Terre, 70, 161-178, 2000.

Neumann, C.: Evidence of predation on Cretaceous sea stars from north-west Germany, Lethaia, 33, 65-70, 2000.

Neumann, C: Shell-breaking predation on Cretaceous sea urchins: Spatial and temporal patterns, GSA (Geological Society of America) Abstracts with Programs, Vol. 35, Abstract No: 50367, 2003.

Neumann, C. and Wisshak, M.: A foraminiferal parasite on the sea urchin Echinocorys: Ichnological evidence from the Late Cretaceous (Lower Maastrichtian, Northern Germany), Ichnos, 13, 185-190, 2006.

Neumann, C. and Wisshak, M.: Gastropod parasitism on Late Cretaceous to Early Paleocene holasteroid echinoids - Evidence from Oichnus halo isp. n., Palaeogeogr. Palaeocl., 284, 115-119, 2009.

Njau, J. K. and Blumenschine, R. J.: A diagnosis of crocodile feeding traces on larger mammal bone, with fossil examples from the Plio-Pleistocene Olduvai Basin, Tanzania, J. Hum. Evol., 50, 142-162, 2006.

O'Gorman, J. P.: New insights on the Aristonectes parvidens (Plesiosauria, Elasmosauridae) holotype: News on an old specimen, Ameghiniana, 53, 397-417, 2016.
Polcyn, M. J. and Bell, G.: The rare mosasaur genus Globidens from north central Texas (Mosasaurinae: Globidensini), J. Vertebr. Paleontol. Supplement, 25, 101A, 2005.

Rahman, I. A., Belaústegui, Z., Zamora, S., Nebelsick, J. H., Domènech, R., and Martinell, J.: Miocene Clypeaster from Valencia (E Spain): Insights into the taphonomy and ichnology of bioeroded echinoids using X-ray micro-tomography, Palaeogeogr. Palaeocl., 438, 168-179, 2015.

Rai, B., Anand, S. C., Madan, M., and Dhattarwal, S. K.: Bite marks: A new identification technique, Internet J. Forensic Sci., 2, 1-5, 2006.

Rana, R. S. and Sati, K. K.: Late Cretaceous-Palaeocene crocodilians from the Deccan trap-associated sedimentary sequences of peninsular India, J. Palaeontol. Soc. India, 45, 123-136, 2000.

Reif, W.-E.: Morphologie und Skulptur der Haifisch-Zahnkronen, N. Jb. Geol. Paläont. Abh., 143, 39-55, 1973.

Robbins, J. A., Ferguson, K. M., Polcyn, M. J., and Jacobs, L. L.: Application of stable carbon isotope analysis to mosasaur ecology, in: Proceedings of the Second Mosasaur Meeting, edited by: Everhart, M. J., Fort Hays State Univ., Hays, Kansas, 123-130, 2008.

Russell, D. A.: Systematics and morphology of American mosasaurs. Peabody Museum of Natural History, Yale University Bulletin, 23, 1-240, 1967.

Sachs, S.: Redescription of Elasmosaurus platyurus Cope 1868 (Plesiosauria: Elasmosauridae) from the Upper Cretaceous (lower Campanian) of Kansas, USA, Paludicola, 5, 92-106, 2005.

Sachs, S., Hornung, J. J., and Reich, M.: Mosasaurs from Germany - a brief history of the first 100 years of research, Neth. J. Geosci., 94, 5-18, 2015.

Salih, K. A. O., Evans, D. C., Bussert, R., Klein, N., Nafi, M., and Müller, J.: First record of Hyposaurus (Dyrosauridae, Crocodyliformes) from the Upper Cretaceous Shendi Formation of Sudan, J. Vertebr. Paleontol., 36, e1115408, https://doi.org/10.1080/02724634.2016.1115408, 2016.

Sato, T.: Terminonatator ponteixensis, a new elasmosaur (Reptilia; Sauropterygia) from the Upper Cretaceous of Saskatchewan, J. Vertebr. Paleontol., 23, 89-103, 2003.

Sato, T.: A new polycotylid plesiosaur (Reptilia: Sauropterygia) from the Upper Cretaceous Bearpaw Formation in Saskatchewan, Canada, J. Paleontol., 79, 969-980, 2005.

Schmid, F., Schulz, M.-G., and Wood, C. J.: The Maastrichtian sections of Hemmoor and Kronsmoor - retrospect, stocktaking and bibliography, Geol. Jb. A, 157, 11-22, 2004.

Schönfeld, J., Schulz, M. G., McArthur, J. M., Burnett, J., Gale, A., Hambach, U., Hansen, H. J., Kennedy, W. J., Rasmussen, K. L., Thirlwall, M. F., and Wray, D. S.: New results on biostratigraphy, palaeomagnetism, geochemistry and correlation from the standard section for the Upper Cretaceous white chalk of northern Germany (Lägerdorf-Kronsmoor-Hemmoor), Mitt. Geol.Paläontol. Inst. Univ. Hamburg, 77, 545-575, 1995.

Schulp, A. S.: Feeding the mechanical mosasaur: what did Carinodens eat?, Neth. J. Geosci., 84, 345-357, 2005.

Schulp, A. S., Vonhof, H. B., van der Lubbe, J. H. J. L., Janssen, R., and van Baal, R. R.: On diving and diet: resource partitioning in type-Maastrichtian mosasaurs, Neth. J. Geosci., 92, 165-170, 2013. 
Schwimmer, D. R., Stewart, J. D., and Williams, G. D.: Scavenging by sharks of the genus Squalicorax in the Late Cretaceous of North America, Palaios, 12, 71-83, 1997a.

Schwimmer, D. R., Stewart, J. D., and Williams, G. D.: Xiphactinus vetus and the distribution of Xiphactinus species in the Eastern United States, J. Vertebr. Paleontol., 17, 610-615, 1997b.

Seilacher, A.: Mosasaur, limpet or diagnesis: how Placenticeras shells got punctured, Mitt. Mus. Naturk. Berlin, Geowiss. R., 1, 93-102, 1998.

Taylor, J. A.: The foods and feeding habits of subadult Crocodylus porosus Schneider in Northern Australia, Aust. Wildlife Res., 6, 347-359, 1979.

Thies, D.: Bisspuren an Seeigel-Gehäusen der Gattung Echinocorys Leske, 1778 aus dem Maastrichtium von Hemmoor (NWDeutschland), Mitt. Geol.-Paläont. Inst. Univ. Hamburg, 59, 7182, 1985.

Tomilin, A. G.: Zveri SSSR I prilezhashchikh stran, Vol. IX, Kitoobraznye, Izdatel'stvo Akademii Nauk SSSR, Moscow, 756 pp., 1957.

Tsujita, C. J. and Westermann, G. E. G.: Were limpets of mosasaurs responsible for the perforations in the ammonite Placenticeras?, Palaeogeogr. Palaeocl., 169, 245-270, 2001.

Vincent, P., Bardet, N., Suberbiola, X. P., Bouya, B., Amaghzaz, M., and Meslouh, S.: Zarafasaura oceanis, a new elasmosaurid (Reptilia: Sauropterygia) from the Maastrichtian phosphates of Morocco and the palaeobiogeography of latest Cretaceous plesiosaurs, Gondwana Res., 19, 1062-1073, 2011.
Visser, I. N.: First observations of feeding on thresher (Alopias vulpinus) and hammerhead (Sphyrna zygaena) sharks by killer whales (Orcinus orca) specialising on elasmobranch prey, Aquat. Mamm., 31, 83-88, 2005.

Voigt, S. and Schönfeld, J.: Cyclostratigraphy of the reference section for the Cretaceous white chalk of northern Germany, Lägerdorf-Kronsmoor: A late Campanian-early Maastrichtian orbital time scale, Palaeogeogr., Palaeocl., 287, 67-80, 2010.

Welles, S. P.: Elasmosaurid plesiosaurs with description of new material from California and Colorado, Mem. Univ. California, 13, 125-254, 1943.

Welles, S. P.: A review of the North American Cretaceous elasmosaurs, Univ. California Publ. Geol. Sci., 29, 47-143, 1952.

Wiffen, J. and Moisley, W. L.: Late Cretaceous reptiles (Families Elasmosauridae and Pliosauridae) from the Mangahouanga Stream, North Island, New Zealand, New Zealand J. Geol. Geophys., 29, 205-252, 1986.

Williston, S. W.: The osteology of the reptiles - 300 S., 191 Abb.; Cambridge, MA, Harvard Univ. Pr., 1925.

Wisshak, M. and Neumann, C.: A symbiotic association of a boring polychaete and an echinoid from the Late Cretaceous of Germany, Acta Palaeontol. Pol., 51, 589-597, 2006. 